\title{
Abbreviated New Animal Drug Application
}

National Cancer Institute

\section{Source}

National Cancer Institute. Abbreviated New Animal Drug Application. NCI Thesaurus.

Code C115123.

Data submitted to an abbreviated new animal drug application. 